\title{
Analysis of Teacher's Professional Ethic in China
}

\author{
Jie Zhang ${ }^{1}$, Xiaoping Yang ${ }^{1} \&$ Qiyong Yang ${ }^{2}$ \\ ${ }^{1}$ Education College, Southwest University, Chongqing, China \\ ${ }^{2}$ Research Center for Basic Education, Chengdu Normal University, Chengdu, Sichuan, China \\ Correspondence: Jie Zhang, Education College, Southwest University, Chongqing, 4000715, China. Tel: \\ 86-152-1377-5532. E-mail: zhangjieyangmail@126.com
}

Received: November 13, 2014 Accepted: November 22, 2014 Online Published: December 2, 2014

doi:10.5539/ass.v11n1p181 URL: http://dx.doi.org/10.5539/ass.v11n1p181

\begin{abstract}
Teachers ' professional ethic is the sum of the codes of conducts and essential virtues. It is special presentation of general professional ethics for teaching career. After analysis the relationship of basic requirement and ultimate goal, humanity and sacralization, ethic and technique about the teacher's professional ethic, this article give the three ideas of teachers ' professional ethic on taking professional responsibility, professional boundaries, establishing service consciousness in the perspective of professional development. Then, end up with the four paths of improving the teacher's professional ethic.
\end{abstract}

Keywords: teachers' professional ethic, China, teacher, moral

\section{Introduction}

Ethics are considered to be the principles and norms that people dealing with the relationship between people and others (Fang, 1994; Zhu, 2002; Jin, 2003). Teachers ' professional ethic is the sum of the codes of conducts and essential virtues. It is special presentation of general professional ethics for teaching career. Teachers ' professional ethics affects the students' development and becomes the model of social ethics in other industries. It is the key component of the quality of teachers, and has become the hot issue of China's education reform as well as the construction for teacher team.

With the development of the society, teachers' professional ethics have been constantly adding new connotation (Pin, Wu, \&Wang, 2012). China's code of teacher's professional ethics has had four amendments. There were six rules for the version in 1984 and it was revised in 1991. Then the code was revised to be eight rules in 1997 and it was added new connotations of the eight rules in 2000. The latest revision of the code was back to six rules with more detailed provisions in 2008. The major principles from the latest rules of the code are patriotic law-abiding, love and dedication, love student, teaching and cultivating, being a model for students, life-long learning. The every revision is based on the characteristics of teacher's professional development and the new problems from the implementation process of the code.

Since the 1980s, debates on connotation and extension of teachers' professional ethics in the education sector emerged with each revision of the code. Practical problems became the focus of public attention during the implement of code. Based on the entire situation, the reasonable paths for thinking about the professional ethic should build on reality of the professional ethics construction of teachers.

\section{Basic Requirement or Ultimate Goal}

At present, people from the Chinese education sector generally recognized importance of teachers' professional ethic in the teaching process. However, there formed two different points of view on the orientation of teachers' professional ethic. Some people argued that teachers' professional ethic should be the basic requirement of teachers (Li, Zhou, Wu, \& Cao, 2014). Teachers who work at schools, should consider the professional ethics as the basic requirement and internalize the rules of code. Therefore, teachers need to put basic requirements of ethical code into personal qualities, in virtue of the education and teaching. This is demonstrated in the management of teachers in two aspects. One is the strict professional ethical standards. Another one is that the professional ethic of teacher becomes the important parts of evaluation and promotion. Other people argued that teachers' professional ethic should be ultimate goal of teaching career (Guo, 2014). By accepting the education and making efforts in teaching exploration teachers can meet the ethical requirements. This is demonstrated in 
the management of teachers in three aspects. Firstly, community and schools to set high standards of professional ethics for teachers. Secondly, offering continuous education and guidance for teachers. Thirdly, making the teachers gradually meet the requirements.

Professional ethic is the foundation and nature of teacher. From this perspective, professional ethic is the basic requirement of teacher. Career objective of imparting knowledge and educating people make the professional ethic have the characteristic of modeling, self-discipline, and dedication. Modeling determines professional ethic is not only the teachers' own code of conduct requirements, but also a mean to educate students. Because students are easily to imitate the teacher's behavior or even ideology. So at the very beginning teachers should try to internalize the rules of code for regulating their own attitudes and behaviors. Meanwhile, the premise for teacher to adjust their own behavior by professional ethic is self-discipline. Because the work of educating is hardly measured by quantities but the level of professional ethic. Then, the work of educating is a kind of dedication because educating is a long-term, endless creativity and hard work. The degree of dedication is actually controlled by the level of teacher's professional ethic.

However, in the history of human morality, the teacher's ethics has always been the highest standards of community ethics and it supposed to be realized by continuing education $(\mathrm{Lu}, 2012)$. From this perspective, many people point out that professional ethic is the ultimate goal. However, such kind of views show the defect that it makes the professional ethic beyond the reality of educating. There are two reasons. Firstly, as a kind of ultimate goal, the professional has become external norm that create a mask for teacher and make them to fit the role without thinking about their own personality and quality. In this case, the professional ethic lose the function of adjusting behavior and providing motives. Secondly, as a kind of ultimate goal, it means that teacher do not to have to meet the goal.

In a word, the professional ethic should be the basic requirement of teachers. Then, it can be divided in to different levels. Step by step, teachers improve the level of ethic by combing their teaching practice.

\section{Humanity and Sacralization}

People say that teacher is the most glorious career of the world. People say that the teachers are the candles. People say teachers are gardeners. People say Teachers are engineers of human souls (Li, 2012). These praises fully affirmed the important role of teachers with the high level of professional ethic and covered with bright "Halo" for teachers. Then, the public formed a sort of awareness that teacher should not to make mistakes and they should sacrifice. In reality, from the perspective of humanity, teachers are normal persons with fresh and blood. Therefore, we should consider more about the humanity not only the dedication of teachers when we do the assessments.

\subsection{The Explanations of Teacher's Humanity}

Humanity is one of the most common and most widespread nature of human's property and is a kind of creature with naturality, sociality and subjectivity (Liu, 1995). The foundation of Humanity is naturality, mainly refers to life and the existence of the object (Gong, 2011). The main life for humans is to survive, the genetic qualities of the breed and various desires. The primary performance of object existence for life is the clothing, food, and housing, and so on to meet their physical needs. Sociality refers to people belongs to the community. Everyone is in a certain of social relations. There is no society without people. People cannot survive and develop without society. Therefore, the most important aspect of humanity is Sociality. It shows the relationship between people and people. Human subjectivity refers to the individual is the subject of a recognition and practice. Existence of the human mind enable individuals consciously and self-knowledge, which is likely that moves to control and dominate life, achieve automatic control. Natural essence of vitality and strength of the people is the basis of the subjectivity. Growth and development of subjectivity is depends on the degree of socialization and its own level of social development. Meanwhile, the existence of subjectivity to encourage people to form certain social relations and produce sociality. So naturality and sociality with penetration of subjectivity and subjectivity can be enhanced and improved in certain conditions.

As an ordinary human being, the presence of naturality make teacher with the pursuit of the needs of material meet, because this is the basis of the individual exists. Sociality Existence make teacher in the lives of certain social relations. It can be a teacher in the term of career. It can be a son, daughter, husband, wife in the term of family members. The presence of subjectivity makes teacher be able to control themselves and their lives to achieve harmony life. In individual Humanity ethic is the core of the contents in human nature, but also the most basic conditions of individual subjectivity. The only people who have high level ethic can form ability to change the world and human itself. Only teachers have high level of professional ethic, they can understand and absorb ideology in the interest of human and social development. 


\subsection{Mental Fluctuations of Teacher with Humanity}

Teachers are just ordinary persons with normal human trait. Therefore, when teachers' naturality and sociality cannot be met, even when threatened, the subjectivity will have some bias.

\subsubsection{Imbalance of Psychology at Low Economic Returns}

With the rapid development of economy, obtaining basic subsistence is the most basic requirements of human nature (GAO, 2005). Being a human being with fresh and blood, teachers also have basic desires and needs shared by ordinary people. Then, the spiritual and material needs of modern society cannot be separated. For example, the needs of audios and home computers are both the needs of substance and the carrier of spirit. The phenomenon of low teacher salary will be persistence in most parts of china. Comparison of some high-income industries that teachers have a psychological imbalance. So some teacher cannot focus on education and teaching jobs.

\subsubsection{Occupational Burnout}

Teacher's occupational burnout is a kind of working state caused by mental fatigue and negative sense of failure under chronically pressure and failed to alleviate the work pressure. (Lin, 2014). The main features of teacher's occupational burnout are following: teachers are irresponsible for teaching and show the tendencies of withdrawing; teachers are lack of enthusiasm; teachers are easily irritable, anxious, and sorrowful during the work time; teachers are often in lower self-esteem from work. It seems that teacher are endowed with higher social expectations than general in modern society. Teachers will feel greater pressure when the social expectations unreachable. Inside of the school, most of the teachers not only have to overwork and Lack of teaching freedom and autonomy, but also have few opportunities to participate in decision-making about schools. Thus, teacher's subjectivity is hard to play which enable teachers to devastate.

\subsubsection{From Humanity to Sacralization}

Teachers cannot concentrate on teaching due to the low economic returns. Teachers ignore occupational burnout state during teaching. These phenomenon are against the professional ethic. However, these phenomenon are produced based on the humanity. The study showed that teachers were more prone to high level of spiritual needs when teachers' basic needs were met (Lin, 2000). Therefore, from the point of human nature, we should not just blame teachers but fully tap the inherent potential of teachers, stabilize their virtues and subjectivity to show teachers 'bright points of the humanity. When the level of ethical virtue in human nature is fully tapped, transformation from humanity to sacralization will be realized.

There are two ways to tap teachers' moral virtue in humanity. First of all, Improving the education methods and management means of teachers is the key. Administrators handle relationship between spiritual and material needs of teachers. Administrators need to know teachers better, care about them and build bridges to communicate with teachers, in order to create a Harmonious interpersonal atmosphere. Though designing challenging work and milestones that can be accomplished to raise the sense of achievement and make the spiritual pursuits come true. Then, teachers should give full play to the self- control of subjectivity role in humanity. Teachers should continue to motivate vocational ideals, update the concepts, and enrich professional knowledge and skills for adapting to the change of education environmental society. Teachers should take the initiative to accept training and mentoring to help themselves get a better development.

\section{Ethic and Technique}

Department of education assess the quality of teachers according to test scores of student. Teacher also evaluate the achievements of student by test scores. Under the system of examination - oriented education in China, these phenomena seems very reasonable. Test scores of student is an indicator of students' level of knowledge, and one of the important sign of teachers' teaching ability. Therefore, the focus on improving students' academic achievements in essence beyond reproach. In fact, when such kind of focus go to the extreme, be the only indicator of education, the educational model is questionable. There are many examples of tragedies happened that caused by excessive attention to students' learning achievements in China. Putting teachers technique equate with students' learning achievements lead to social and moral value decay, lack of innovative spirit of humanism. The ancient sage says that the correct way is to lay equal stress on teachers' professional ethic and technique.

\subsection{The Relationship between Teachers' Professional Ethic and Technique}

The technique of teacher prefer to teachers' teaching ability (Zeng \& Li, 2005). There three aspects of the ability: Firstly, general cognitive abilities of teachers that include general mental ability of conscious perception, memory, imagination and thinking. Secondly, special abilities that make sure teacher can conduct the normal 
teaching activities include oral communicative competence and activities designing and organizing abilities. Thirdly, professional knowledge that be full of profound cultural quality and depth of knowledge, have some knowledge of pedagogy and psychology, follow the rules of pedagogy and psychology to complete the task of teaching.

The relationship of teachers' professional ethic and technique is not contradictory, but interdependence, interaction and mutually reinforcing. Teachers' professional ethic can guide the technique and the technique can present professional ethic. Teachers' professional ethic can provide direction of technique and also be incentive to do their job. Teachers' professional ethic cannot be effected without professional basis and teaching abilities.

\subsection{Teachers Teaching the Theory of Knowledge and Teacher Cultivating Student's Personality}

In ancient China, teachers were divided to be two types. One is the kind of teacher who just teach theory of knowledge according to the textbook. The other kind of teacher not only transfer the knowledge but also try their best to cultivate the student's personality. In modern society, we also have the two types of teachers. Teachers whose teaching goals just aim to the students' testing scores belongs to the first type and they just focus on skills of professional with ignoring ethical impact. Teachers who influence students with their own charisma and cultivate the ethic, ability and personality of students belong to be the second type of teacher with the high level of professional ethic.

\section{The Three Core Ideas in the Perspective of Professionalization}

\subsection{Take Responsibility for Professional Development}

Traditionally, teachers were responsible for whole "nation" which is the most abstract word, though shoulder the tasks of mainstream values and cultural transmission. In recent years, due to the discovery and the stress of the rights of the child, there are comments and views about that teachers should be responsible for the students (Dai \& Dong, 2014).Who should be the right object for teachers to take responsibility for? The administrators of the nation or the students or the both. There comes the contradictions that lead to the teacher's ethical dilemmas.

There are professional associations or professional bodies that were made up of professional individuals, in addition to various community organizations. In order to maintain the social order within the organization, whether it be business or other type of social organization will develop internal management rules. Similarly, in order to maintain the social order of the industry, professional associations or professional bodies should also be entered into an ethical code, to practice behaviors of employees of the statute. All rules are reflected in the professional spirit of being responsible. Teachers should recognize that as a professional, not only responsible for the state and students but also for their professional development.

In advanced western countries, many professional associations with knowledge as the basis foundation of their professional development all have their own ethical code to guide the members' conducts. Especially industries of academic or professional bodies with people who are closely associated, like psychologists, sociologists, doctors, lawyers, accountants, architects and so on. However, things are different in China according to the stage of socio - economic development. Chinese learn some sort of expertise system from the western countries, mostly use it as a tool to make a living. Many intellectuals treat their expertise without a high degree of loyalty and just as a tool to fight to fame and benefits. Therefore, teachers should take the responsibility for professional development and education.

\subsection{Professional Boundaries}

There is no doubt that in the development of the Child, teachers with the professional education abilities have a very heavy responsibility. Because teachers' income from tuition and state revenue, it does not meet the characteristics of teachers' professional and public interest if teachers take little responsibilities. However, if teachers' responsibilities extend to infinity can only reduce the educational responsibility. Community should have appropriate expectation for schools and teachers (and not excessive), so that schools and teachers effectively take responsibility for education. In a word, we should pay more attention to the reasonable boundaries of the responsibility.

\subsection{Service Consciousness}

New nature of education, it's clear that it is an unprecedented nature of the service; it is services for students learning. Education is a sort of special service for 4 aspects. Firstly, education services are not available as objects but as activities of the service. Secondly, Education services have a special value, different from the general service or enjoying the purpose of material consumption, to effectively promote the healthy development of students for the purpose of educational services. Thirdly, education services with the synchronic features of 
time and space between producers and consumers. Educators and the educated people both have the power to do the potential impact of the education and penetrating to the whole process of education. Fourthly, education services require that educators have a high sense of responsibility, and in a humane manner to grasp and reflect the equity of education and spirituality. Establishment of teachers' professional services consciousness are an important aspect of the quality of teachers' professional ethics to improve.

\section{Four Paths to Improve Teachers' Professional Ethics}

\subsection{Ethical Education}

Ethical education is the educational administrative departments and all levels of teachers 'schools ( including Teachers' College ) to take effective measures to improve the teaching guidelines for teachers on social thought, such as codes of conduct awareness of the concept system and form a proper perspective for evaluation of right and wrong, beauty, good and evil. Ethical education was organized by administrative departments and schools in order to raise awareness among teachers and establish a correct concept. There are many pacific ways to develop the education. Such as lectures of professional ethics, forums of professional ethics, speeches of professional ethics, typical positive reports of professional ethics.

\subsection{Teachers' Ethical Management}

Teachers' ethical management was conducted by educational administrative departments and schools by system, evaluation, atmosphere to create environments to help teachers to experience the psychological feeling of professional ethic, so that teachers can overcome the ethical dilemmas and raise the level of ethics gradually. We can realize the management by supervision, praise, making rules, process evaluation.

\subsection{Construction of Teachers' Professional Ethic}

Teachers' ethical construction is also conducted by educational administrative departments and schools though the ways of designing the goal and carrying agent to effectively guide teachers consciously adjust their behaviors and emotions. During the process, teachers would overcome all kinds of difficulties, change the thinking pattern of work pattern, and adhere to the correct behavior. Therefore, the construction of teachers' professional ethic play a key role of developing the professional ethic.

\subsection{Self-refining of the Professional Ethic}

Self-refining of the professional ethic is a sort of project for self - training, self - rebuilding and self improvement. It is following the professional ethical code. It is the start and the end of the journey for improving the ethical level. The contents of the self- refining including professional ideal, professional responsibility, professional attitude, professional discipline, occupational skills, professional conscience, professional honor.

\section{Acknowledgements}

This article presents a partial output of a research funded by Primary Cultural Transformation in The Process of Urbanization in Sichuan Province Grant of Sichuan Province Philosophy Social Sciences Research "Twelve-Five" Plan (SCI3XK32), and by Universal Pre-k Education in Poor Areas of China in Grant of Ministry of Education of China "Twelve-Five" Plan (DHA120235)

\section{References}

Cao, Y. C. (2014). Is the Soul of teachers of teachers' morality? Staff education in China, 2, 63.

Dai, Y. L. (2014). Training of primary school teachers' professional responsibility. Education of the times, 18, 9.

Dong, Y. W. (2014). Love and responsibility of the teacher's responsibility. Journal of Jilin Institute of Education (Middle), 8, 99-100.

Fang, L. S. (1994). Dictionary of Chinese philosophy (p. 269). China Social Sciences Publishing House.

Gao, H. S. (2005). On several characteristics of human needs. Journal of Theoretical Guide magazine, 2, 34-35.

Gong, L. P. (2011). From the ideological and political education of human - oriented Interpretation of Marxist view of human nature. Journal of Group of the world, 20, 255.

Guo, J. W. (2014). Teachers' morality construction in colleges and universities. Journal of Changchun Institute of Technology (Social Science Edition), 3, 24-27.

Jin, B. H. (2003). Dictionary of Marxism Philosophy (p. 645). Shanghai publisher of dictionaries.

L, S. J. (2012). A Brief Talk on necessity of strengthening teachers' moral cultivation of young teachers. The new curricula (continued), 10, 32 . 
Li, G. C., Zhou, G. C., \& Wu, X. S. (2014). Teachers' morality is the source of "life" for Teachers. Huanggang Daily, 8,30 .

Li, X. D. (2012). On teachers' professional ethics from the candle burning. Education in Guizhou, 2, 9.

Lin, C. D. (2000). Browse through teachers' ethics (p. 21). Shandong Education Press.

Lin, Y. X. (2014). Analysis on the Countermeasures of teachers' job burnout. Science and Technology in Gansu Province, 5, 50-60.

Liu, X. Y. (1995). Responsibilities of teachers from the education functions of human nature. Journal of the Yibin College, 4, 66-68.

Pin, L., Wu, D. J., \& Wang, C. L. (2012). Probe into the Connotation of teacher's professional ethics construction under the new situation. Occupation, S1, 13.

Zeng, T., \& Li, L. (2003). A survey of teachers' teaching ability. Shaoxing College of Arts and Sciences Journal (Philosophy and Social Sciences Edition), 1, 102-105.

Zhu, Y. T. (2002). Dictionary of ethics (p. 14). Shanghai publisher of dictionaries.

\section{Copyrights}

Copyright for this article is retained by the author(s), with first publication rights granted to the journal.

This is an open-access article distributed under the terms and conditions of the Creative Commons Attribution license (http://creativecommons.org/licenses/by/3.0/). 